\title{
Diet quality and therapeutic targets in patients with type 2 diabetes: evaluation of concordance between dietary indexes
}

\author{
Juliana Peçanha Antonio ${ }^{1,3^{*}}$, Vanessa Costa da Rosa ${ }^{2}$, Roberta Aguiar Sarmento 1,3 \\ and Jussara Carnevale de Almeida 2,3
}

\begin{abstract}
Background: This study aimed to evaluate the concordance between two dietary indexes, the Healthy Eating Index (HEI) and the Diabetes Healthy Eating Index (DHEI), in evaluating diet quality and its possible association with therapeutic targets in patients with type 2 diabetes.

Methods: Cross-sectional study of outpatients with type 2 diabetes mellitus treated at a university hospital. Dietary information was obtained from a quantitative food frequency questionnaire (previously validated for use in patients with type 2 diabetes) and converted into daily intakes. Diet quality was assessed using two dietary indexes: HEl (12 components, nine food groups and three moderation components) and DHEl (10 components, six food groups, three nutrient groups, and one for variety of diet). In both indexes, the sum of the scores for each component yields an overall score converted on a scale from 0 to 100\%; diet quality is subsequently ranked as low ( $<51 \%)$, needing improvement $(51-80 \%)$, or high $(>80 \%)$. Patients underwent clinical and laboratory assessment. Those with fasting blood glucose values $70-130 \mathrm{mg} / \mathrm{dL}, \mathrm{A} 1 \mathrm{c}<7 \%$, total cholesterol $<200 \mathrm{mg} / \mathrm{dL}$, $\mathrm{LDL}$-cholesterol $<100 \mathrm{mg} / \mathrm{dL}$, and triglycerides $<150 \mathrm{mg} / \mathrm{dL}$ were considered to meet therapeutic targets. All analyses were conducted in PASW Statistics 18.0, and $p<0.05$ deemed significant.

Results: We analyzed 148 patients with type 2 diabetes (73\% white, mean age $63.2 \pm 9.4$ years, median diabetes duration 10 [IQR 5-19] years, mean A1c\% $8.4 \pm 2.0 \%$, and mean BMI $\left.30.5 \pm 4.2 \mathrm{~kg} / \mathrm{m}^{2}\right)$. Mean energy intake was $2114 \pm 649 \mathrm{kcal} /$ day. DHEl scores were $17.0(95 \% \mathrm{Cl}-6.8$ to 41.0$)$ points lower than HEl scores $(55.9 \pm 14.2 \%$ vs. $72.9 \pm 10.7 \%$, respectively; $P<0.001$ ), suggesting there is no agreement (Bland-Altman method), and the Pearson correlation coefficient was $0.55(P<0.001)$. More patients were classified as having a low-quality diet by the DHEl than by the HEl (38.5\% vs. 1.4\%; $P<0.001)$. A higher proportion of patients $(35.7 \%)$ with out-of-target total cholesterol levels had a low-quality diet evaluated by the DHEI $(P=0.03)$. We did not find associations between overall score of HEl and therapeutic targets.
\end{abstract}

Conclusions: In its intended population of patients with type 2 diabetes, the DHEl seems to be a more rigorous tool to evaluate association between diet quality and changes in metabolic parameters.

Keywords: Dietary indexes, Diet quality, Diabetes mellitus type 2

\footnotetext{
* Correspondence: juantonio@hcpa.edu.br

${ }^{1}$ Endocrinology Division, Hospital de Clínicas de Porto Alegre (HCPA), Rua

Ramiro Barcelos, 2350, Prédio 12,4 andar, Porto Alegre, RS 90035-003, Brazil

${ }^{3}$ Centro de Estudos em Alimentação e Nutrição (CESAN), HCPA/UFRGS, Porto

Alegre, Rio Grande do Sul, Brazil

Full list of author information is available at the end of the article
} 


\section{Background}

Diabetes mellitus (DM) is a complex, chronic illness characterized by a heterogeneous set of metabolic disorders, including hyperglycemia and impaired carbohydrate, protein, and lipid metabolism, caused by abnormalities in insulin action and/or secretion [1]. It is consolidated as a serious public health problem at the national and international level, due to its high prevalence, marked morbidity and mortality, and the costs involved in its treatment, parallel to the increasing prevalence of obesity and sedentary lifestyle [1]. The adoption of healthy behaviors, especially changes in diet and physical activity, is an appropriate foundation for a DM self-management program of, and can serve as a basis for people with DM to achieve a healthy lifestyle [2].

Among nutritional recommendations for DM, the following dietary composition is recommended: 45 to $60 \%$ of daily calories from total carbohydrates (intake of not less than $130 \mathrm{~g} /$ day), 15 to $20 \%$ of daily calories from protein (or 0.8 to $1 \mathrm{~g} / \mathrm{kg} /$ weight), and 25 to $35 \%$ of daily total calories from lipids. The latter are stratified as follows: $<7 \%$ of daily calories from saturated fatty acids (SFA), up to $10 \%$ of daily calories from polyunsaturated fatty acids (PUFAs), 5 to $15 \%$ of daily calories from monounsaturated fatty acids (MUFAs), and daily cholesterol intake less than $300 \mathrm{mg}$ [3]. The minimum dietary fiber recommendation is $14 \mathrm{~g}$ per $1000 \mathrm{kcal}$, with priority given to whole grains, vegetables, and fruits [3]. Under Brazilian guidelines, the recommended intake of vitamins and minerals is for individuals without diabetes [4], while sodium consumption should not exceed $2000 \mathrm{mg}$ per day, which is equivalent to $5 \mathrm{~g}$ of cooking salt (i.e., one teaspoon of salt at most) [3].

Dietary indexes have been recommended to monitor adherence to nutritional recommendations among individuals and populations [5]. Several instruments are available to evaluate diet quality, among which the Healthy Eating Index (HEI) [6] stands out because it considers consumption both of food groups and of specific nutrients [6]. Recently, the Diabetes Healthy Eating Index (DHEI) [7] was developed, taking into account nutritional recommendations for this population, with the objective of evaluating diet quality and testing for possible associations with health outcomes in diabetics. Some studies have assessed the dietary quality of patients with DM, but none has used a dietary index that contemplates specific recommendations for this population $[8,9]$. In this context, the objective of the present study was to compare the agreement of two dietary indexes (HEI and DHEI) to evaluate diet quality and possible association with therapeutic targets in patients with type 2 diabetes.

\section{Methods}

\section{Study population}

This was a cross-sectional study of outpatients with type 2 DM treated at Hospital de Clínicas de Porto Alegre
(HCPA), a tertiary referral center in Southern Brazil, who were consecutively selected for the study "Quality of usual diet and health outcomes in patients with type 2 diabetes mellitus". The diagnosis of type 2 DM was established as follows: disease onset after 30 years of age, no previous episodes of ketoacidosis or documented ketonuria, and treatment with insulin only $\geq 5$ years after diagnosis [10]. Patients were included according to the following criteria: not having received dietary counseling from a nutritionist for at least 6 months prior to the study, age $<80$ years, body mass index $(\mathrm{BMI})<40 \mathrm{~kg} / \mathrm{m}^{2}$, serum creatinine $<2 \mathrm{mg} / \mathrm{dL}$, normal thyroid function tests, and no kidney diseases (other than diabetic nephropathy), severe liver disease, decompensated heart failure, or any acute and/or consumptive illness. The study was conducted in accordance with the Declaration of Helsinki, and all procedures involving patients were approved by the Hospital de Clínicas de Porto Alegre Research Ethics Committee. Written informed consent was obtained from all patients.

\section{Clinical and anthropometric evaluation}

Ethnicity information was obtained by self-report. Economic status was evaluated by a questionnaire designed according to the Brazilian reality [11]. The diagnosis of hypertension was established from readings obtained with an Omron model HEM-705CP blood pressure monitor [12]. The patient was considered hypertensive when mean systolic pressure was $\geq 140 \mathrm{mmHg}$ or diastolic pressure $\geq 90 \mathrm{mmHg}$ on at least two separate occasions, measured $1 \mathrm{~min}$ apart, or was receiving pharmacological treatment for hypertension, independently of blood pressure levels [13]. Diabetic nephropathy was assessed from spot urinary albumin excretion measurement; patients with values $\geq 14 \mathrm{mg} / \mathrm{L}$ were considered to have renal disease [14].

The anthropometric measurements used to assess nutritional status were weight (measured with patients wearing light clothing and barefoot), height, and waist circumference (measured at the midpoint between the lowest rib and the iliac crest) [15]. These measurements were obtained with an anthropometric scale and an inelastic fiberglass tape measure. BMI was calculated with the formula weight $(\mathrm{kg}) /$ height $(\mathrm{m})^{2}$ [16] and its target value was set at $<25 \mathrm{~kg} / \mathrm{m}^{2}$ [1]

\section{Dietary assessment}

Food intake information was obtained from a quantitative food frequency questionnaire (FFQ), previously validated in patients with type $2 \mathrm{DM}$ [17], which contains 80 items with 10 food groups. A photo album was used to help patients select serving sizes. Reported intake was converted into daily consumption, and diet quality was evaluated using two dietary indexes: the HEI [6] and the DHEI [7]. 
Intake of individual portions was adjusted to a daily caloric intake of $1000 \mathrm{kcal}$. The Brazilian food composition table was used to evaluate the nutritional composition of the FFQ items [18].

The latest version of the HEI, used in this study, consists of 12 components [19]: nine food groups ("total fruit", including 100\% natural fruit juices; "whole fruit", excluding juices and extracts; "total vegetables"; "greens and beans"; "whole grains"; "dairy"; "total protein foods"; "seafood and plant proteins"; "fatty acids", distinguishing unsaturated and saturated) and three items referring to components to be consumed in moderation ("refined grains", "sodium", and "empty calories", i.e., calories from solid fats, alcoholic beverages, and added sugar). The HEI is described in detail in Table 1. Individual scores range from 0 to 20 points, and the sum of the scores of each component yields a percent global score.

The DHEI [7] consists of 10 components: six food groups ("fruit", including fruit juices; "vegetables"; "carbohydrates and sources of fiber"; "meat and eggs"; "dairy and saturated fat"; "oils and fats"), three components referring to "percent daily calorie intake from lipids", "dietary cholesterol", and "trans fatty acids"; and a "diet variety" component. For the last component, each food was counted only when consumption was $>50 \%$ the recommended intake in the corresponding food group. A score had been established for each component, the value of which is classified according to adherence to current national nutritional recommendations for DM, namely: "poor" (zero points), "fair" (one-half point), and "good" (one point) [7]. The sum of the scores of each component yields an overall score of diet quality, which it converted on a scale of zero to 100. The DHEI is described in detail in Table 2. In both indexes, the overall diet quality is classified as low $(<51 \%)$, needing improvement (51-80\%), or adequate (> 80 points) [19].

\section{Laboratory measurements}

Blood samples were obtained after a 12-h fast. Plasma glucose was determined using the glucose oxidase method (biodiagnostica Kit) [20]; glycated hemoglobin (HbA1c, reference range 4.7-6.0\%), by high-precision chromatography in a Merck-Hitachi 9100 system [21]; and total cholesterol, high-density lipoprotein (HDL) cholesterol, and triglycerides (TG) by enzymatic colorimetric methods [22]. Low-density lipoprotein (LDL) cholesterol was calculated using the Friedewald eq. ( $\mathrm{LDL}=$ total cholesterol HDL - TG/5) [23]. Serum creatinine was measured by the Jaffé method [24]. All tests were performed at the Clinical Pathology Laboratory, Hospital de Clínicas de Porto Alegre.

\section{Statistical analysis}

The distribution of variables was assessed using the Shapiro-Wilk test. Data were expressed as mean \pm standard deviation or absolute and relative frequency (\%), as indicated. Comparison of overall diet quality between the dietary indexes was done using the paired $t$-test. Analysis of concordance between the HEI and DHEI was performed using the Bland-Altman plot method, which evaluates the mean difference between two methods and considers the variability in these differences among individuals [25]. Poisson regression models were used to test for possible associations between individual component and overall diet quality of each of the dietary indexes with therapeutic targets (dependent variable). Analyses were adjusted to possible confounding variables selected according to clinical relevance. A chi-square test was used to evaluate the relationship between diet quality categories within each index and the achievement of therapeutic targets (outcomes). All data analyses were performed in PASW Statistics 18.0 (SPSS Inc., Chicago, IL), and the type I error rate was set at 5\% (two-tailed).

Table 1 Healthy Eating Index (HEI) components and criteria used for maximum score and zero score [19]

\begin{tabular}{|c|c|c|c|}
\hline Components & Maximum Score & Maximum score criteria & Criteria for zero score \\
\hline 1. Total fruit (includes fruit juice) & 5 & $\geq 0.8$ cup per $1000 \mathrm{kcal}$ & No fruit or juice \\
\hline 2. Whole fruit (includes all forms except juice) & 5 & $\geq 0.4$ cup per1000 kcal & No whole fruit \\
\hline 3. Total vegetables & 5 & $\geq 1.1$ cup per $1000 \mathrm{kcal}$ & No vegetables \\
\hline 4. Greens and beans & 5 & $\geq 0.2$ cup per $1000 \mathrm{kcal}$ & No dark green vegetables or legumes \\
\hline 5. Whole grains & 10 & $\geq 40 \mathrm{~g}$ per $1000 \mathrm{kcal}$ & No whole grains \\
\hline 6. Dairy & 10 & $\geq 1.3$ cup per1000 kcal & No dairy \\
\hline 7. Total protein foods & 5 & $\geq 70 \mathrm{~g}$ per $1000 \mathrm{kcal}$ & No protein foods \\
\hline 8. Seafood and plant proteins & 5 & $\geq 20 \mathrm{~g}$ per $1000 \mathrm{kcal}$ & No seafood or plant protein \\
\hline 9. Fatty acids & 10 & $(P U F A s+M U F A s) / S F A s \geq 2.5$ & $($ PUFAs + MUFAs $) /$ SFAs $\leq 1.2$ \\
\hline 10. Refined grains & 10 & $\leq 50 \mathrm{~g}$ per $1000 \mathrm{kcal}$ & $\geq 120 \mathrm{~g}$ per $1000 \mathrm{kcal}$ \\
\hline 11. Sodium & 10 & $\leq 1.1 \mathrm{~g}$ per $1000 \mathrm{kcal}$ & $\geq 2$ g per 1000 kcal \\
\hline 12. Empty calories & 20 & $\leq 19 \%$ of energy & $\geq 50 \%$ of energy \\
\hline
\end{tabular}

PUFAs polyunsaturated fatty acids, MUFAs monounsaturated fatty acids, SFAs saturated fatty acids 
Table 2 Diabetes Healthy Eating Index (DHEI) components and criteria for adherence [7]

\begin{tabular}{|c|c|c|c|c|}
\hline \multirow[t]{2}{*}{ Components (daily intake) } & \multirow[t]{2}{*}{ Portion (kcal) [27] } & \multicolumn{3}{|c|}{ Criteria for adherence with diabetes recommendations } \\
\hline & & Poor & Fair & Good \\
\hline 1. Diet variety: number of items & - & $<6$ & $6-16$ & $\geq 16$ \\
\hline 2. Fresh fruit (portions per 1000 kcal) & 70 & $<1.0$ & $1.0-1.5$ & $\geq 1 \frac{1}{2}$ \\
\hline 3. Vegetables (portions per 1000 kcal) & 15 & $<1.0$ & $1.0-1.5$ & $\geq 1 \frac{1}{2}$ \\
\hline $\begin{array}{l}\text { 4. Carbohydrates and fiber sources } \\
\text { (portions per } 1000 \mathrm{kcal} \text { ) }\end{array}$ & 150 & $<3$ & $\begin{array}{l}<3 \\
\text { BUT at least } 50 \% \text { from } \\
\text { fiber sources }\end{array}$ & $\begin{array}{l}\geq 3 \\
\text { AND at least } 50 \% \text { from } \\
\text { fiber sources }\end{array}$ \\
\hline $\begin{array}{l}\text { 5. Meat and eggs (portions per } \\
1000 \text { kcal) }\end{array}$ & 190 & $>1.0$ & $0.5-1.0$ & $\leq 0.5$ \\
\hline $\begin{array}{l}\text { 6. Dairy products (portions per } \\
1000 \text { kcal) AND saturated fatty acids } \\
\text { (\% of energy) }\end{array}$ & 120 & $\begin{array}{l}<0.75 \text { portion/day of dairy } \\
\text { OR saturated fatty acids } \\
\text { intake }>10.5 \% \text { of energy }\end{array}$ & $\begin{array}{l}>0.5 \text { portion of dairy AND } \\
\text { Saturated Fatty Acids } \\
<7.0 \% \text { of energy } \\
\text { OR } \\
>0.75 \text { portion of dairy AND } \\
\text { saturated fatty acids between } \\
7.0 \text { and } 10.5 \% \text { of energy }\end{array}$ & $\begin{array}{l}1.0-2.0 \text { portions/day of } \\
\text { dairy AND saturated fatty acids } \\
<7 \% \text { of energy }\end{array}$ \\
\hline $\begin{array}{l}\text { 7. Oils, fats, and nuts (portions } \\
\text { per } 1000 \mathrm{kcal} \text { ) }\end{array}$ & 73 & $>1.0$ & $0.5-1.0$ & $\leq 0.5$ \\
\hline 8. Total lipids (\% of energy) & - & $\geq 45 \%$ & $30-45 \%$ & $\leq 30 \%$ \\
\hline 9. Dietary cholesterol (mg/day) & - & $\geq 450$ & $300-450$ & $\leq 300$ \\
\hline $\begin{array}{l}\text { 10. Trans-unsaturated fatty acids } \\
\text { (\% of energy) }\end{array}$ & - & $\geq 1.5 \%$ & $1.0-1.5 \%$ & $\leq 1.0 \%$ \\
\hline
\end{tabular}

Criteria for adherence were based on the Brazilian Society for Diabetes [3], Brazilian Dietary Guidelines [27], and original HEl [6] for classification of the diet variety component

Estimation of sample size was based on a pilot study previously performed in a subsample of 201 patients with type $2 \mathrm{DM}$, in which diet quality evaluated by the original HEI [6] was found to differ from DHEI scores $(80.2 \pm 11.7 \%$ vs. $61.7 \pm 11.5 \%$, respectively, $P<0.001)$. Thus, expecting a difference in diet quality of at least $10 \%$ among dietary indexes and considering a type I error of $5 \%$ and a type II error of $10 \%, 58$ patients would be necessary.

\section{Results}

A total of 148 patients with type 2 DM were consecutively included after the pilot study and were analyzed. Mean age was $63.2 \pm 9.4$ years; $73 \%$ were white, and $62.8 \%$ female. Mean A1c was $8.4 \pm 2.0 \%$, and mean BMI, $30.5 \pm$ $4.2 \mathrm{~kg} / \mathrm{m}^{2}$. Regarding dietary characteristics, the mean reported total calorie intake was $2114 \pm 649 \mathrm{kcal} /$ day. Table 3 describes demographic, clinical, lifestyle, and laboratory characteristics of the sample.

Fig. 1 shows the Bland-Altman plots between the two dietary indexes. The mean difference (agreement range) observed between diet quality score evaluated by the HEI as compared to DHEI was 17.0 points $(95 \% \mathrm{CI}-6.8$ to 41.0 ; $P<0.001)$.

Pearson correlation between the overall diet quality assessed by the two indexes was calculated as $r=0.55$ $(P<0.001)$, and is shown in Fig. 2 . More patients were classified as having a low-quality diet by the DHEI than by the HEI $(38.5 \%$ vs. $1.4 \%$; $P<0.001)$.

Poisson regression models were also used to test for possible associations between overall diet quality of each of the dietary indexes and their individual components with therapeutic targets (dependent variable). Regarding the HEI, some individual components as total fruit, total protein foods, whole grains, sodium, empty calories and fatty acids were associated with therapeutic targets. Regarding the DHEI, other individual components as vegetables, meat and eggs, dietary cholesterol, and overall diet quality were associated with therapeutic targets (see Additional file 1).

A higher proportion of patients (35.7\%) with out-oftarget total cholesterol levels had a low-quality diet evaluated by the DHEI $(P=0.03)$. No association was found between overall HEI score and any of the therapeutic targets evaluated.

\section{Discussion}

The overall diet quality score from the two dietary indices in this sample of 148 patients with type $2 \mathrm{DM}$ was $72.9 \pm$ $10.7 \%$ in the HEI and $55.9 \pm 14.2 \%$ in the DHEI $(P<0.001)$. The mean score yielded by both instruments classified diet as "needing improvement", similar to what was found in a recent systematic review of studies that evaluated diet quality in the Brazilian population [26]. Among the 
Table 3 Demographic, clinical, lifestyle and laboratory characteristics of patients with type 2 diabetes

\begin{tabular}{|c|c|}
\hline \multicolumn{2}{|l|}{ Characteristic } \\
\hline $\mathrm{N}$ & 148 \\
\hline Age (years) & $63.2 \pm 9.4$ \\
\hline Female & $62.8 \%$ \\
\hline White skin color & $73.0 \%$ \\
\hline Lower middle class & $46.0 \%$ \\
\hline Years of study & $7.1 \pm 3.7$ \\
\hline Duration of diabetes (years) & $10[5-19]$ \\
\hline \multicolumn{2}{|l|}{ Hypertension } \\
\hline Systolic blood pressure (mmHg) & $140.8 \pm 21.9$ \\
\hline Diastolic blood pressure (mmHg) & $76.5 \pm 11.5$ \\
\hline Current smoking & $6.8 \%$ \\
\hline Micro- or macroalbuminuria & $24.2 \%$ \\
\hline BMI $\left(\mathrm{kg} / \mathrm{m}^{2}\right)$ & $30.5 \pm 4.2$ \\
\hline $\mathrm{BMI}>30 \mathrm{~kg} / \mathrm{m}^{2}$ & $56.1 \%$ \\
\hline \multicolumn{2}{|l|}{ Waist circumference (cm) } \\
\hline Males & $105.5 \pm 10.9$ \\
\hline Females & $101.9 \pm 9.9$ \\
\hline \multicolumn{2}{|l|}{ Diabetes treatment } \\
\hline Diet alone & $2.7 \%$ \\
\hline Oral agents & $43.2 \%$ \\
\hline Insulin & $6.1 \%$ \\
\hline Insulin plus oral agents & $48.0 \%$ \\
\hline Hypolipidemic agents & $68.2 \%$ \\
\hline Fasting plasma glucose (mg/dL) & $161.3 \pm 71.9$ \\
\hline A1c (\%) & $8.4 \pm 2.0$ \\
\hline $\mathrm{A} 1 \mathrm{C}<7 \%$ & $27.0 \%$ \\
\hline Total cholesterol (mg/dL) & $174.7 \pm 40.2$ \\
\hline Total cholesterol <200 mg/dL & $53.4 \%$ \\
\hline HDL cholesterol (mg/dL) & $41.9 \pm 10.0$ \\
\hline Males & $40.5 \pm 8.9$ \\
\hline Females & $42.8 \pm 10.6$ \\
\hline LDL cholesterol (mg/dL) & $100.6 \pm 34.4$ \\
\hline LDL cholesterol <100 mg/dL & $50.7 \%$ \\
\hline Triglycerides (mg/dL) & $163.2 \pm 88.2$ \\
\hline Triglycerides $<150$ mg/dL & $44.6 \%$ \\
\hline Serum creatinine (mg/dL) & $0.8 \pm 0.2$ \\
\hline Glomerular filtration rate $\left(\mathrm{mL} / \mathrm{min} / 1.73 \mathrm{~m}^{2}\right)$ & $83.7 \pm 22.3$ \\
\hline Glomerular filtration rate $>90 \mathrm{~mL} / \mathrm{min} / 1.73 \mathrm{~m}^{2}$ & $20.9 \%$ \\
\hline
\end{tabular}

Data presented as mean \pm standard deviation, median [interquartile range] or $\mathrm{n}(\%)$

main results of the present study, we observed a moderate correlation between the two dietary indexes and a significant difference in the overall diet quality of approximately 17 points, as shown by the Bland-Altman plot method, suggesting that there is no agreement between the two instruments.

Thus, a greater propensity for rigidity of the DHEI is noted, possibly because it follows specific recommendations for the evaluated population. More patients were classified as having poor diet quality by the DHEI than by the HEI (38.5\% vs. $1.4 \%, P<0.001$ ), and a higher proportion of patients $(35.7 \%)$ with out-of-target total cholesterol levels had a low-quality diet evaluated by the DHEI $(P=0.03)$.

Associations between individual HEI consumption scores of components total fruit, total protein foods, whole grains, sodium, empty calories and fatty acids with therapeutic targets were observed $(P<0.05)$. Regarding the DHEI, some individual components as vegetables, meat and eggs, dietary cholesterol, and overall diet quality were associated with therapeutic targets $(P<0.05)$ after adjustment for confounders. However, a larger sample is needed to confirm these findings.

Recent studies evaluated the diet quality of patients with DM, but did not use a specific dietary index designed to take nutritional recommendations for this population into account $[8,9]$. Regarding the association with health outcomes, only one cross-sectional study, conducted in a Korean population with type 2 DM [8], evaluated the association between glycemic control and diet quality as assessed by three dietary indexes: Diet Quality Index (DQI), alternative HEI, and Healthy Diet Indicator (HDI). The authors found an inverse correlation between DQI and HDI diet quality scores and A1c\% $(r=-0.21, P<0.05$, $r=-0.28, P<0.05$, respectively), blood glucose $(\mathrm{r}=-0.21$, $P<0.05, r=-0.23, P<0.05$, respectively), and postprandial glycaemia $(r=-0.30, \quad P<0.05 ; \quad r=-0.26, \quad P<0.05$, respectively). Diet quality assessment with the alternative HEI was not associated with any of the outcomes evaluated.

Studies of diet quality in patients with DM are still scarce in the literature, especially when it comes to the use of instruments designed specifically for this population. In the present study, we used a new dietary index based on current nutritional recommendations for DM, with internal validity tested in a previous study [7]. Our objective was to evaluate its agreement with a widely used index [19] and to verify associations with therapeutic targets in type $2 \mathrm{DM}$.

The limitations of this study include the difficulty of comparing our results with those of other studies conducted in different populations of individuals with type 2 DM. In addition, use of these instruments is still beset by unanswered questions, such as which inferences can actually be drawn from their results and whether they are in fact able to evaluate the quality of eating habits as a whole without considering the impact of each food group has on overall diet quality. These methodological questions need to be evaluated carefully through repeated 


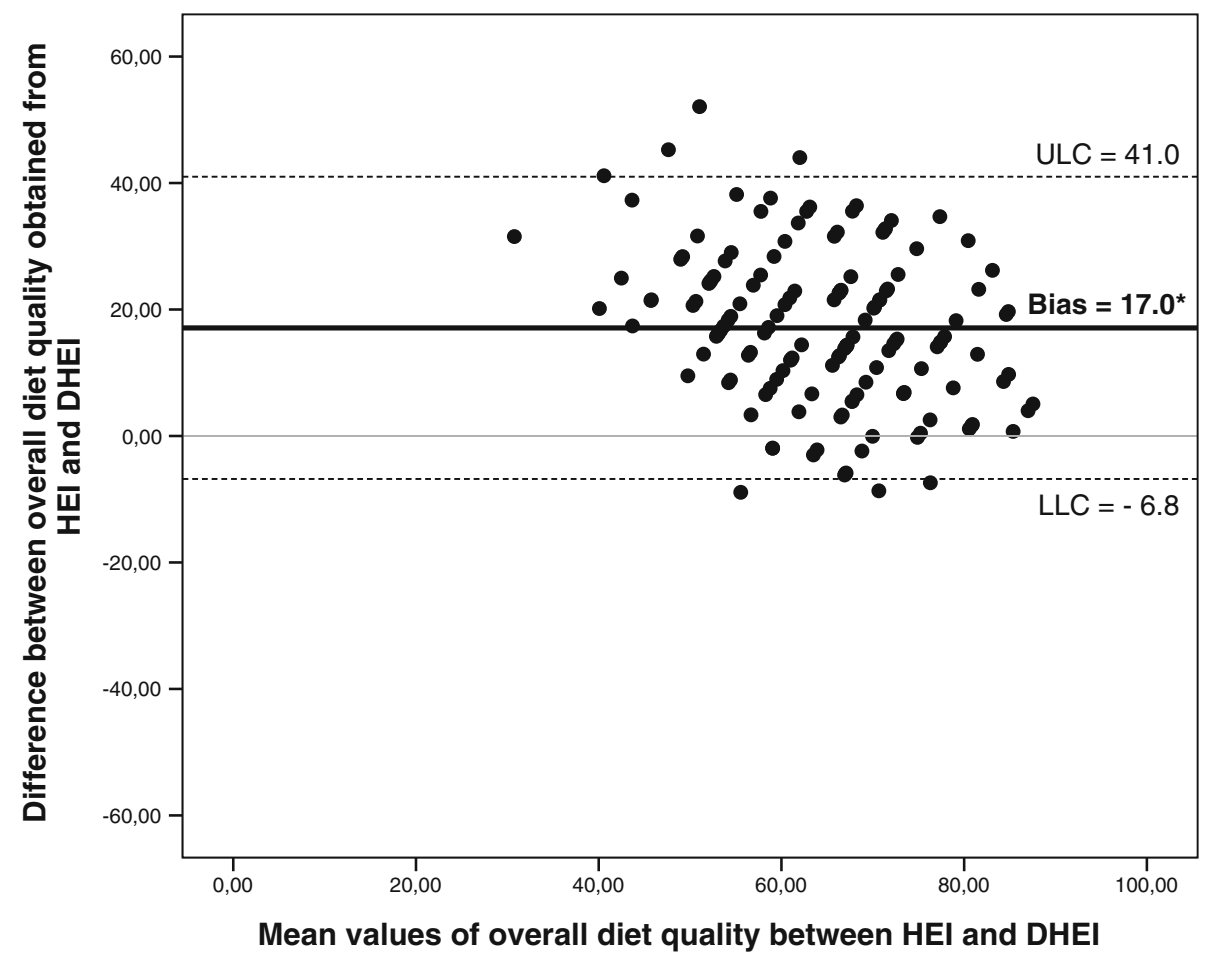

Fig. 1 Bland-Altman plot between HEl and DHEl for determining overall diet quality of patients with type 2 diabetes $(n=148)$. The solid line represents the mean difference between the two instruments, and the dotted lines represent the minimum and maximum differences between HEI and DHEI, where LLC is the lower limit of concordance and ULC is the upper limit of concordance

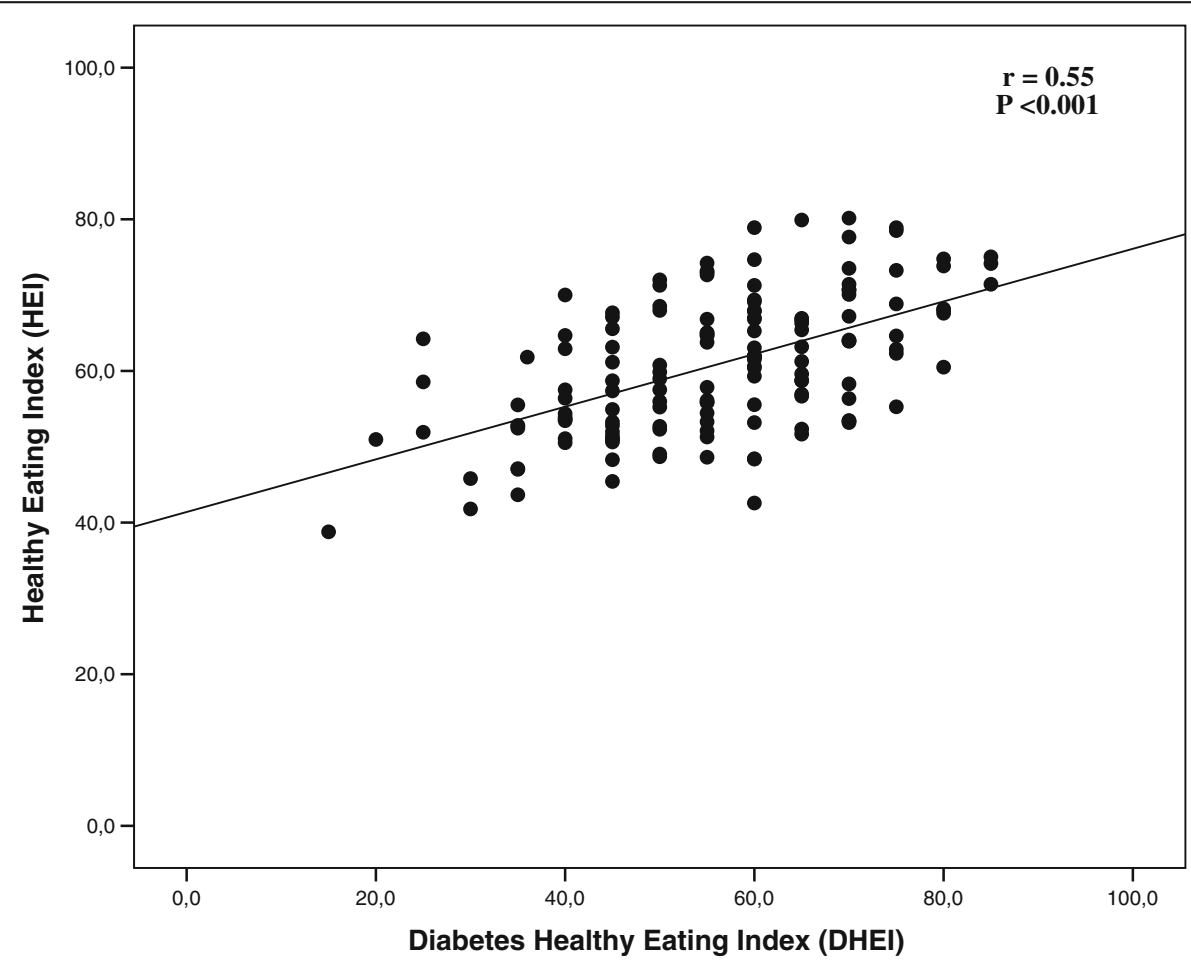

Fig. 2 Pearson correlation coefficients ( $r$ ) between HEl and DHEl scores in patients with type 2 diabetes $(n=148)$ 
application in different populations if classification of diet quality is to become more reliable.

\section{Conclusion}

The two instruments tested in this study (HEI and DHEI) had a moderate correlation, but no agreement. The DHEI seems to be a more rigorous instrument for evaluating the association between diet quality and achievement of metabolic targets in patients with type 2 DM.

\section{Additional files}

Additional file 1: Poisson regression models between overall diet quality and individual components of dietary indexes with therapeutic targets (dependent variable) in patients with type $2 \mathrm{DM}(n=148)$ (DOCX $21 \mathrm{~kb})$

\section{Abbreviations}

BMI: Body mass index; DHEl: Diabetes healthy eating index; DM: Diabetes mellitus; DQI: Diet quality index; FFQ: Food frequency questionnaire; HDI: Healthy diet indicator; HDL: High-density lipoprotein; HEl: Healthy eating index; LDL: Low-density lipoprotein; MUFAs: Monounsaturated fatty acids; PUFAs: Polyunsaturated fatty acids; SFA: Saturated fatty acids; TG: Triglycerides

\section{Acknowledgements}

This study was supported by Fundo de Incentivo à Pesquisa e Eventos, Hospital de Clínicas de Porto Alegre.

\section{Funding}

Not applicable.

\section{Availability of data and materials}

The datasets used and/or analyzed during the current study are available from the corresponding author on reasonable request.

\section{Authors' contributions}

JPA and VCR contributed to data collection and manuscript writing. JPA, RAS, and JCA contributed to the statistical analysis and interpretation of data. JPA and JCA reviewed the manuscript critically for important intellectual content and discussed the results. All authors read and approved the final version of the manuscript.

\section{Ethics approval and consent to participate}

The present study is part of a larger project titled "Quality of Usual Diet and Health Outcomes in Patients with Type 2 DM", which was approved by the Hospital de Clinicas de Porto Alegre Research Ethics Committee (number 13-0489). All patients included in this study signed informed consent forms, and data collection followed Declaration of Helsinki guidelines and Brazilian National Health Council Resolution 466/2012

\section{Consent for publication}

Not applicable.

\section{Competing interests}

The authors declare that they have no competing interests.

\section{Publisher's Note}

Springer Nature remains neutral with regard to jurisdictional claims in published maps and institutional affiliations.

\section{Author details}

${ }^{1}$ Endocrinology Division, Hospital de Clínicas de Porto Alegre (HCPA), Rua Ramiro Barcelos, 2350, Prédio 12,4 andar, Porto Alegre, RS 90035-003, Brazil. ${ }^{2}$ Universidade Federal do Rio Grande do Sul (UFRGS), Porto Alegre, Rio
Grande do Sul, Brazil. ${ }^{3}$ Centro de Estudos em Alimentação e Nutrição (CESAN), HCPA/UFRGS, Porto Alegre, Rio Grande do Sul, Brazil.

Received: 31 January 2017 Accepted: 6 November 2017

Published online: 21 November 2017

\section{References}

1. American Diabetes Association (ADA). Standards of medical Care in Diabetes. Diabetes Care. 2017;40(Suppl 1):S1-2.

2. American Diabetes Association (ADA). Lifestyle Management. Diabetes Care. 2017:40(Suppl 1):S33-43.

3. Sociedade Brasileira de Diabetes (SBD). Diretrizes da Sociedade Brasileira de Diabetes. Princípios para Orientação Nutricional no Diabetes Mellitus 2015-2016; 91-106.

4. Dietary Reference Intakes - DRls. http://www.nap.edu/read/11537/chapter/3\#4. Acessed 24 Jan 2017.

5. Volp ACP, Alfenas RCG, Costa NMB, Minim VPR, Stringueta PC, Bressan J. Índices dietéticos para avaliação da qualidade de dietas. Rev Nutr. 2010;23: 281-95.

6. Kennedy ET, Ohls J, Carlson S, Fleming K. The healthy eating index: design and applications. J Am Diet Assoc. 1995;10:103-8.

7. Antonio JP, Silva FM, Camey SA, Azevedo MJ, Almeida JC. Development of a healthy eating index for patients with type 2 diabetes. Rev Nutr. 2015;28: 513-22.

8. Kim JY, Cho YY, Park YM, Sohn CM, Rha MY, Lee MK, et al. Association of Dietary Quality Indices with Glycemic Status in Korean Patients with Type 2 Diabetes. Clin Nutr Res. 2013;2:100-6.

9. Murray AE, McMorrow AM, O'Connor E, Kiely C, Mac Ananey O, O'Shea D, et al. Dietary quality in a sample of adults with type 2 diabetes mellitus in Ireland; a cross-sectional case control study. Nutr J. 2013;12-110.

10. World Health Organization (WHO). Definition, diagnosis and classification of diabetes mellitus and its complications. In: Part 1: diagnosis and classification of diabetes mellitus. Geneva: World Health Organization (WHO); 2003.

11. Associação Brasileira de Empresas de Pesquisa (ABEP). Critério de Classificação Econômica Brasil. São Paulo, 2015. http://www.abep.org/ Servicos/Download.aspx?id=09\&p=cb. Acessed 24 Jan 2017.

12. O'Brien E, Waeber B, Parati G, Staessen J, Myers MG. Blood pressure measuring devices: recommendations of the European Society of Hypertension. BMJ. 2001;322:531-6.

13. Chobanian AV, Bakris GL, Black HR, Cushmann WC, Green LA, Izzo DW, et al. The seventh report of the joint national committee on prevention, detection, evaluation, and treatment of high blood pressure: the JNC 7 report. JAMA. 2003;289:2560-72.

14. Sociedade Brasileira de Diabetes (SBD). Diretrizes da Sociedade Brasileira de Diabetes. Doença Renal do Diabetes 2015-2016; 150-65.

15. Gibson RS, Rosalind S. Anthropometric assessment of growth, Chapter 10 in Principles of nutritional assessment. Second edition. United Kingdom: Oxford University Press; 2005. p. 195.

16. World Health Organization (WHO). Global Database on Body Mass Index. BMI classification. 2006. http://www.assessmentpsychology.com/icbmi.htm. Acessed 24 Jan 2017.

17. Sarmento RA, Antonio JP, Riboldi BP, Montenegro KR, Friedman R, Azevedo MJ, et al. Reproducibility and validity of a quantitative FFQ designed for patients with type 2 diabetes mellitus from southern Brazil. Public Health Nutr. 2013;17:2237-45.

18. Ministério do Desenvolvimento Social e Combate à Fome. Tabela Brasileira de Composição de Alimentos - TACO $4^{a}$ edição revisada e ampliada. Campinas, Brasil 2011. http://www.cfn.org.br/wp-content/uploads/2017/03/ taco_4_edicao_ampliada_e_revisada.pdf. Acessed 24 Jan 2017.

19. Guenther PM, Casavale KO, Reedy J, Kirkpatrick SI, Hiza HA, Kuczynski KJ, et al. Update of the Healthy Eating Index: HEl-2010. J Acad Nutr Diet. 2013; 113:569-80.

20. Trinder P. Determination of blood glucose using an oxidase-peroxidase system with a noncarcinogenic chromogen. J Clin Pathol. 1969:22:148-61.

21. Camargo JL, Zelmanovitz T, Paggi A, Friedman R, Gross JL. Accuracy of conversion formulae for estimation of Glycohaemoglobin. Scand J Clin Lab Invest. 1998;58:521-8.

22. Farish $\mathrm{E}$, Fletcher $\mathrm{CD}$. A comparison of two micro-methods for the determination of HDL2 and HDL3 cholesterol. Clin Chim Acta. 1983;129:221-8. 
23. Friedewald WT, Levy RL, Fredrickson DS. Estimation of the concentration of low-density lipoprotein cholesterol in plasma, without use of the preparative ultracentrifuge. Clin Chem. 1972;18:499-502.

24. Fabiny DL, Ertingshousen G. Automated reaction-rate method for determination of serum Creatinine with the Centrifichem. Clin Chem. 1971; 15:696-704.

25. Bland JM, Altman DG. Measuring agreement in method comparison studies. Stat Methods Med Res. 1999;8:135-60.

26. Moreira PRS, Rocha NP, Milagres LC, Novaes JF. Análise crítica da qualidade da dieta da população brasileira segundo o Índice de Alimentação Saudável: uma revisão sistemática. Ciênc Saúde Coletiva. 2015; 10.1590/ 1413-812320152012.18352015.

27. Guia Alimentar para a População Brasileira: promovendo a alimentação saudável. Brasília, Brasil. Ministério da Saúde. 2008. 210p. http://bvsms.saude. gov.br/bvs/publicacoes/guia_alimentar_populacao_brasileira_2008.pdf. Acessed 24 Jan 2017.

Submit your next manuscript to BioMed Central and we will help you at every step:

- We accept pre-submission inquiries

- Our selector tool helps you to find the most relevant journal

- We provide round the clock customer support

- Convenient online submission

- Thorough peer review

- Inclusion in PubMed and all major indexing services

- Maximum visibility for your research

Submit your manuscript at www.biomedcentral.com/submit
Biomed Central 